\title{
複数構造物に作用する津波波力に関する 3 次元数值シミュレーション 3D-Simulation of Tsunami Wave Force on Multiple Structures
}

\author{
四條利久磨 ${ }^{1} \cdot$ 佐藤敏浩 $^{2} \cdot$ 池末俊一 $^{3}$ \\ Rikuma SHIJO, Toshihiro SATO and Shunichi IKESUE
}

\begin{abstract}
In the Tohoku-Pacific Ocean Earthquake, many onshore structures were destroyed by the tsunami, the wave height of which exceeded the conventional assumption. In the future, the reinforcement of tsunami disaster prevention measures will be needed, and the evaluation of tsunami wave force on onshore structures will be very important. To evaluate the tsunami wave force on onshore structures, it is necessary to deal with tsunami run-up as a three-dimensional flow. In this study, a three-dimensional simulation is applied to tsunami run-up around structures. And the applicability of the three-dimensional simulation is examined for the evaluation of tsunami wave force on onshore structures.
\end{abstract}

\section{1. はじめに}

2011 年の東北地方太平洋沖地震では, 従来の想定を超 える巨大な津波が発生し，陸上に遡上した津波によって 数多くの構造物が損壊した. 今後，沿岸部における津波 対策の強化が求められるが，その検討に当たっては，沿 岸構造物に作用する津波波力の評価が重要となる.

津波波力の評価においては, 地形変化に伴う津波の変 形や陸上への遡上, 及び構造物との干渉等, スケールの 異なる複数の現象を同時に考慮する必要がある．特に， 構造物周りについては，構造物前面における遡上津波の 打ち上がりや構造物背後への回り込み等の現象が津波波 力の大きさに影響するものと考えられる. したがって， 構造物に作用する津波波力を評価するには，遡上津波の 流動現象を 3 次元流れとして取り扱う必要がある.

このような構造物周りにおける遡上津波の流動状況を 考慮するには，3次元の数值シミュレーションが有効と 考えられる．例えば中村ら（2009）は，遡上津波の変形 と陸上構造物に作用する津波波力について，3次元数值 シミュレーションの適用性を検討している．ただし，前 述のとおり津波波力の評価には，スケールの異なる現象 を同時に考慮する必要があり，計算格子の取扱い等の面 で3次元数值シミュレーションの適用には未だ制約が大 きい. したがって，陸上構造物に対する津波波力の評価 への3次元数值シミュレーションの適用事例は少ないの が現状である.

そこで本研究では, 計算格子の取扱いが比較的容易な 沉用の流体解析コードを用い, 既往の模型実験に関する 公開論文との比較によって，3次元数值シミュレーショ ンの適用性を検討した。

\begin{tabular}{llll}
\hline 1 & 正会員 & 工修 & 三菱重工業(株)技術統括本部長崎研究所 \\
2 & 非会員 & 工博 & 三菱重工業(株)技術統括本部長崎研究所 \\
3 & 正会員 & 工博 & 三菱重工業(株)技術統括本部長崎研究所
\end{tabular}

\section{3次元数值シミュレーション}

本研究では, 汎用の流体解析コードとしてANSYS 社 のFLUENTを用いた. 同コードは有限体積法をベースと した非構造格子のソルバーを有しており，非圧縮性流体 から圧縮性流体まで，層流から乱流まで広範な問題をモ デル化する機能を有している。

また，この解析コードでは，混相流を取扱う手法とし てVOFモデルを有しており, 自由表面流れの問題にも適 用可能である.

ここで，計算領域における津波の生成には境界条件の 取扱いが必要となるが, FLUENTでは境界条件や流れ状 態のソース項等についても，ユーザー定義関数の機能を 有している．ユーザー定義関数では，C言語ベースのプ ログラミングによって，ユーザー自身で境界条件等をカ スタマイズすることができる．

本研究では，これらの機能を用いて公開論文における 津波実験の再現を試み，3次元数值シミュレーションの 適用性を検討した。

なお，本研究では中村ら（2009）の論文を参考として， 乱流モデルにLES（Large-Eddy Simulation）を用い，自由 表面の捕捉にはVOF（Volume of Fluid）モデルを用いた.

\section{3. 垂直壁に作用する津波波圧に関する 3 次元数 值シミュレーション}

陸上構造物に作用する津波の波力/波圧は，海底地形等 の影響によって変化する，朝倉ら（2000）は，直立護岸 を越流した遡上津波の津波波力特性を明らかにする目的 で，2次元水理実験を実施している。この実験では陸上 構造物に模した垂直壁へ作用する波圧について計測が行 われており，海底勾配等の条件を変化させた場合におけ る波圧特性も検討されている.

そこで本研究では，まず朝倉ら（2000）の論文を参考 
として垂直壁に作用する津波波圧の3 次元数值シミュレ ーションを実施し，その適用性を検討した。計算は図-1 に示すように，朝倉ら（2000）の実験と同スケールの条 件で実施した。

なお，本研究では，朝倉ら（2000）の実験結果から， 波圧として最大となる波高 $0.2 \mathrm{~m}$ ・周期 $42 \mathrm{~s}$ ・ 引き波初 動・海底勾配 $1 / 50$ のケース, 及び周期が特に長い津波を 除いて波圧として最小となる波高 $0.2 \mathrm{~m}$ ・周期 $42 \mathrm{~s}$ ・引き 波初動・海底勾配 1/200のケースを対象とした。参考と して, 海底勾配 1/50のケースに打ける護岸・垂直壁近傍 の計算格子の一例を図-2に示す。ここでは, 護岸・垂直 壁近傍に計算格子を集約し, 水面から遠方の空気層につ いては, 計算負荷の軽減を考慮し, 粗い格子分割として 総格子数を削減するようにしている.

計算領域における津波の生成については,流入境界条件 として次式で与えられる津波の水平流速 $u$ と水位 $\eta$ を入 カした

$$
u=\eta \sqrt{\frac{g}{h}}
$$

$$
\eta=-\frac{H}{2} \sin \left(\frac{2 \pi}{T} t\right)
$$

ここに, $g$ は重力加速度 $\left(\mathrm{m} / \mathrm{s}^{2}\right), h$ は水深 $(\mathrm{m}), H$ は波 高 $(\mathrm{m}), T$ は周期 $(\mathrm{s}), t$ は時間 $(\mathrm{s})$ である。式 $(1)$, （2）については，ユーザー定義関数を作成して，境界条 件に組み込んだ。

また，朝倉ら（2000）の論文では，波条件は一様水深 部における值である旨が示されている。 そこで，今回の シミュレーションでは, 図-1のスロープ入り口（一様水 深部とスロープの境界位置) に打ける第一波の水位の山 と谷の高低差が $0.2 \mathrm{~m}$ となるよう，式（2）の波高 $H$ を調 整した。な扔，計算では，遡上した第 1 波による垂直壁 の波圧を再現した。

図-3に，遡上水深の時刻歴波形に関する計算結果を示 す。計算結果から，海底勾配 $1 / 50$ と1/200のケースにつ いて，構造物前面での遡上水深に差異が生じていること が分かる．ここで，VOF 值 0.5 の等值面として描いた水 面と鉛直断面の流速コンターを併記したものを図-4に示 すが，これからも海底勾配 $1 / 50$ としたケースは，海底勾

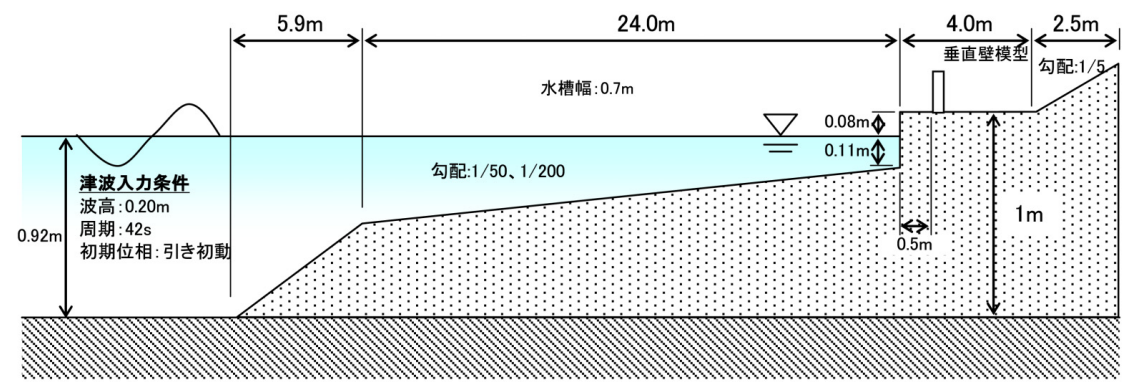

図-1 3 次元数值シミュレーションに用いた条件 ※朝倉ら（2000）を参考とした

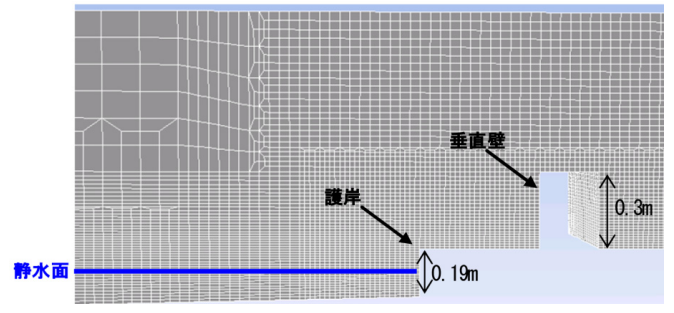

図-2 計算格子例

（海底勾配 $1 / 50 ，$ 護岸・垂直壁近傍）

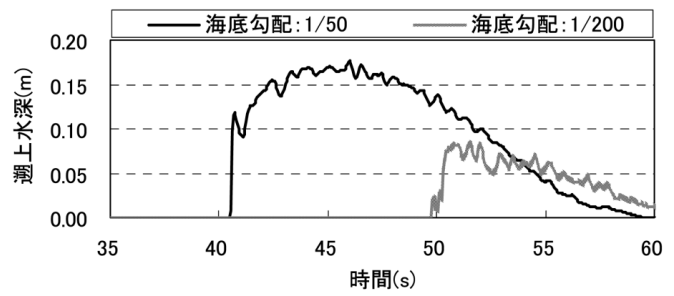

図-3 遡上水深の時刻歴波形 (垂直壁前面における遡上水深の計算結果)
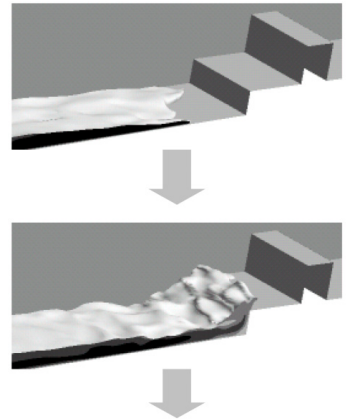

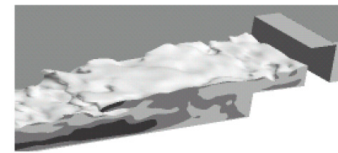

(a)海底勾配 1/50
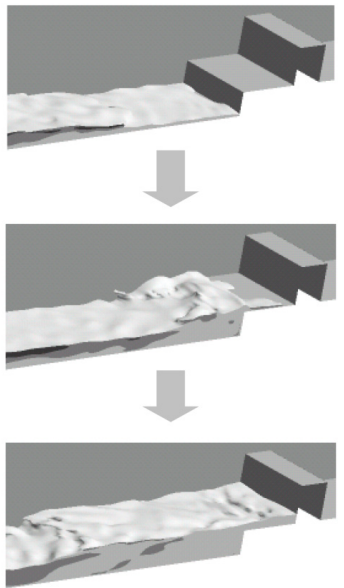

(b)海底勾配 1/200

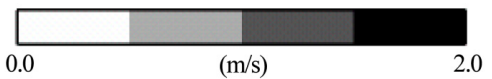

図-4 護岸・垂直壁近傍における水面形及び流速コンター （流速コンターは鉛直断面の流速絶対值を表記） 

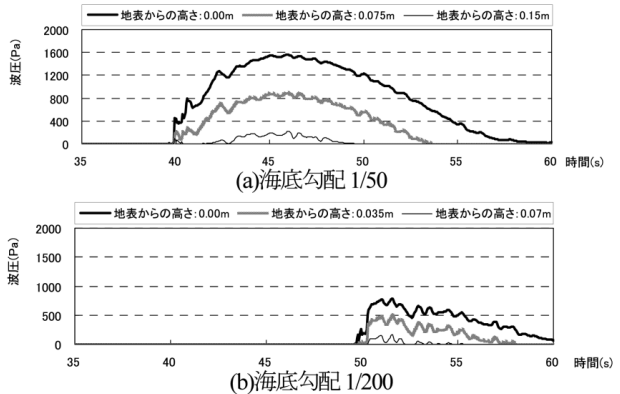

図-5 波圧の時刻歴波形

（垂直壁前面における波圧の計算結果）

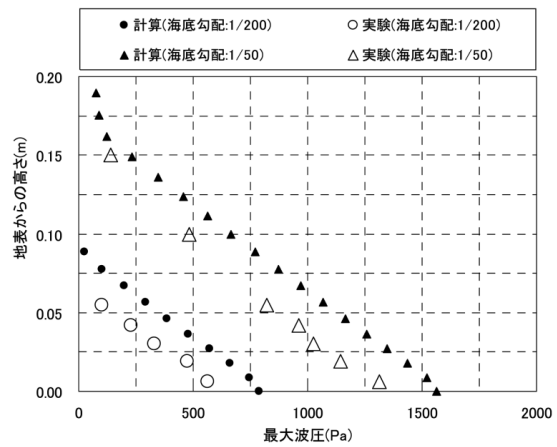

図-6 最大波圧の鉛直分布（実験結果：朝倉ら (2000)

配 1/200としたケースに対して, 護岸を乗り越える津波 水量が多いことが分かる。これは，海底勾配の違いによ って, 進行してくる津波先端部の進行速度に差異が生じ ているためと考えられる。この違いが，護岸における津 波の乗り越え挙動，及び垂直壁前面での遡上水深に影響 しているものと考えられる.

図-5に垂直壁前面における波圧の時刻歴波形を示す. この結果から，遡上水深と同様に波圧についても海底勾 配 1/50のケースの方が海底勾配 1/200のケースに比べて 大きなピーク值となっていることが分かる．また，波圧 の波形は図-3に示した遡上水深の波形と相似となってい
る.例えば，海底勾配 $1 / 50$ のケースでは， $\mathrm{t}=45 \mathrm{~s}$ 付近に て遡上水深が $0.15 \mathrm{~m}$ 程度のピーク值となるが，垂直壁最 下部の波圧についても $\mathrm{t}=45 \mathrm{~s}$ 付近で $1500 \mathrm{~Pa}$ 程度のピーク 值となり，遡上水深の静水圧相当の值となっている．朝 倉ら（2000）は，垂直壁に作用する波圧が遡上水深に基 づく静水圧と相似となる旨結論付けており，計算結果も これと同様の傾向となっている.

図-6に，垂直壁に作用する最大波圧の鉛直分布を示す. 図-6には朝倉ら（2000）の論文に示された実験結果の読 取值を併記しているが，最大波圧が直線分布となること， 海底勾配の違いによって波圧の大きさが異なることがシ ミュレーションでも定性的に再現されている.

\section{4. 複数構造物に作用する津波波力に関する 3 次 元数値シミュレーション}

朝倉ら（2000）の論文では，実験水路幅とほぼ同等の 幅となる垂直壁模型によって, 断面 2 次元的な津波波力 の特性に関する実験的検討が行われている。一方で，実 際の構造物においては，遡上した津波が構造物前面で打 ちあがるだけでなく, その流れが構造物の背面に回りこ むため, 現象がより複雑となる。また，構造物が複数配 置される場合には, 周囲の構造物との干渉によって遡上 津波の波力が影響を受けるものと考えられる。したがっ て, 実際の構造物へ作用する遡上津波の波力を評価する には，これらの3次元的な影響も考慮する必要がある.

そこで本研究では，シマモラら（2007）が実施した矩 形構造物に作用する津波波力の水槽実験, 及び同実験を 対象とした中村ら（2009）の数值シミュレーションを参 考として，複数構造物に作用する津波波力に対する 3 次 元数值シミュレーションの適用性を検討した.

シミュレーションに用いた条件を図-7に示す。シマモ ラら（2007）は，水槽実験により，陸上に配置された矩 形構造物に作用する津波波力を計測し，また，矩形構造 物を単体で配置した場合と複数配置した場合の津波波力

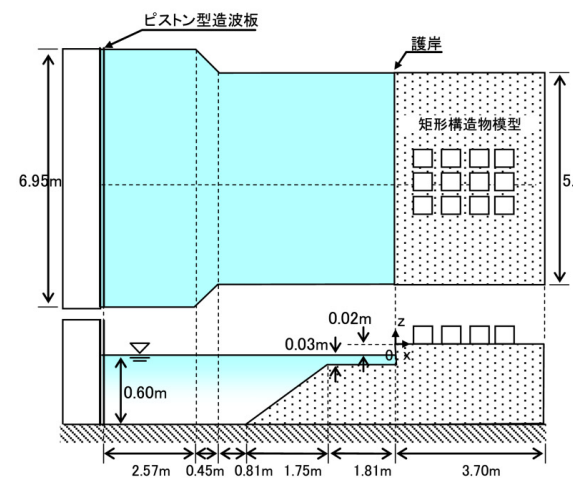

(a) 水槽諸元

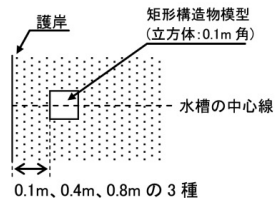

$0.1 \mathrm{~m}, 0.4 \mathrm{~m}, 0.8 \mathrm{~m}$ の 3

(b) 模型配置 (単体)

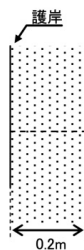

(c) 模型配圈 (䙉数)

図-7 3 次元数值シミュレーションに用いた条件 ※シマモラら（2007），中村ら（2009）を参考とした 
の違いについて明らかにしている。

中村ら（2009）は，シマモラら（2007）の実験を対象 として，独自に開発した 3 次元数值シミュレーションモ デルの適用性を検討している. 中村ら（2009）のモデル では，SMAC法をベースとした流速と圧力の連成計算に 加えて，自由表面を捕捉するためのモデルとしてMARS 法（Multi-Interface Advection and Reconstruction Solver）が 用いられている。MARS 法は自由表面の勾配を考慮した VOF值の輸送モデルであり, 各計算セルのVOF值から自 由表面を捕捉するVOFモデルの1種と考えることができ る. また，この中村ら（2009）のモデルでは乱流モデル としてLESが用いられている.

以上を参考として，本研究では図-7に示すように矩形 構造物が単体配置する場合と複数配置する場合の 2 ケー スを対象とした 3 次元数值シミュレーションを行った。

ここで，シミュレーションに用いた計算格子を図-8に 示す. 垂直壁のケースと同様に, 護岸・矩形構造物近傍 における計算格子を詳細に分割し, それ以外の領域を粗 く分割するような構成としている。また，シミュレーシ ヨンにおける津波の造波については，シマモラら（2007） の水理実験で用いられたピストン型造波板の変位波形か ら造波板の速度を求めて, FLUENTの移動計算格子機能 により直接造波板の動きを模擬している。この方法で得 られた水位波形の計算結果，及び中村ら（2009）の論文 に記載された実験結果・計算結果との比較を図-9に示す

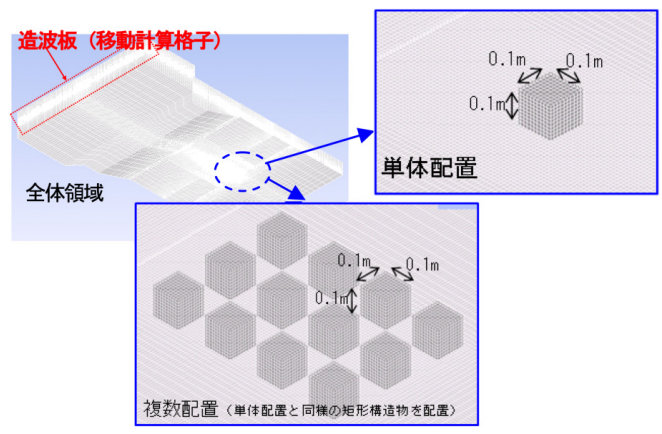

図-8 解析格子

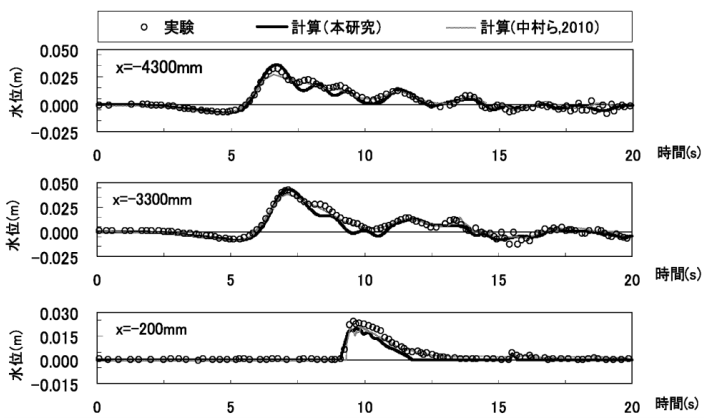

図-9 水位波形 ( $\mathrm{x}$ ：護岸からの位置，負值が沖方向 $)$
が，計算領域内での津波水位が計算にて概ね良好に再現 出来ていることを確認している.

図-10に，矩形構造物を単体配置した場合の護岸から の距離と最大津波波力の関係を示す。図-10には，シマ モラら（2007）の論文に示された実験結果の読取值を併 記しているが，矩形構造物の設置位置が護岸から離れる にしたがって最大津波波力が小さくなる傾向をシミュレ ーションでも定性的に再現できていることが分かる。ま た, 矩形構造物を護岸から $0.2 \mathrm{~m}$ 位置, $0.4 \mathrm{~m}$ 位置に設置し た場合については，定量的にも計算と実験は良好に一致 している．ただし，矩形構造物を護岸から $0.8 \mathrm{~m}$ 位置に設 置した場合については, 計算結果が実験結果に比べて大 きい結果となっている. 地表部及び構造物周辺の格子サ イズを水平・鉛直共に $1 / 2$ とした場合も，図-10 と同様の 結果となった。ここで, 矩形構造物を単体で配置する場 合, 護岸と矩形構造物との間における遡上津波のエネル ギーの減衰は, 護岸を乗り越えた直後の3 次元流動影響 と地表の粗度に起因する摩擦抵抗によって生じるものと 考えられる。一方で, 今回のシミュレーションでは, 護 岸を乗り越える際の3 次元流動は直接再現しているもの の, 摩擦抵抗については地表部分に滑面に対するNonSlip 条件を付与しているのみである. したがって, 今後 の精度向上には粗度影響のユーザー定義関数導入が必要 と考えられ，これが今後の取り組み課題といえる.

矩形構造物が複数配置される場合には，構造物との干 渉影響によって遡上した津波が減勢し, 後列側の矩形構 造物に作用する波圧が低下する。図-11に計算結果の事

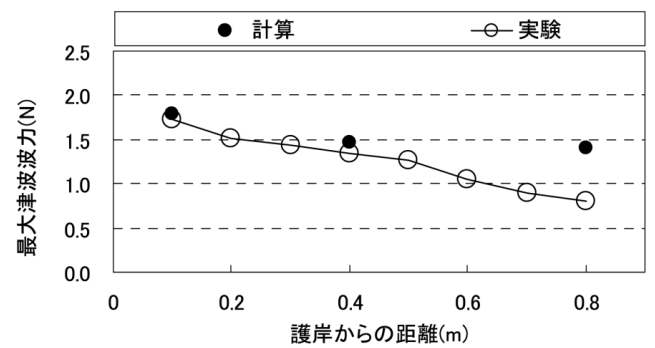

図-10 護岸からの距離と最大津波波力の関係 （単体配置の場合，実験結果：シマモラら（2007））

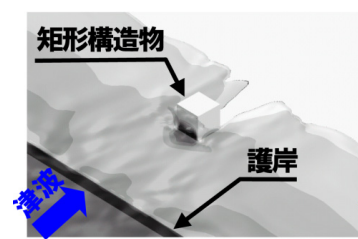

(a)単体配置のケース

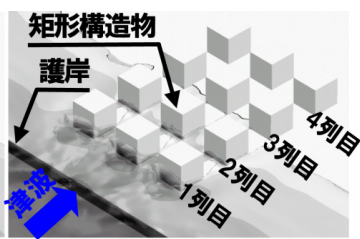

(b)複数配置のケース

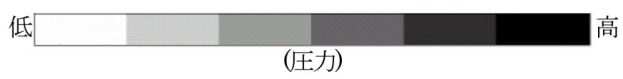

図-11 圧力コンター (単体配置は護岸から $0.4 \mathrm{~m}$ 位置) 
例として構造物周りにおける圧力のコンター図を示す が，今回実施した3次元数值シミュレーションでもこの 傾向が定性的に再現されていることが分かる.

複数配置した場合の矩形構造物に作用する最大津波波 力を図-12 に示す。ここに, 図-12 に示した結果は, 複数 配置した矩形構造物のうち中央に並んだ列の結果を示し ている．図-12にはシマモラら（2007）の論文に示され た実験結果の読取值を併記しているが，計算と実験は良 好に一致している．特に，複数配置のケースで後列側の 波力が大きく低下する現象についても，3次元数值シミ ユレーションによる再現性は良好である。

単体配置の場合とは異なり, 矩形構造物が複数配置さ れる場合には, 周辺構造物によって生じる3 次元流動の 影響が，遡上津波のエネルギー減衰の主因になるものと 考えられる。したがって，図-12の結果は，周辺構造物 の影響を考慮する場合に打ける3 次元数值シミュレーシ ヨンの有用性を示しているものといえる.

護岸から $0.4 \mathrm{~m}$ 位置に単体配置した矩形構造物と, 複数 配置の場合の護岸から $0.4 \mathrm{~m}$ 位置に配置された矩形構造物 について，最大津波波力の比較を図-13に示す．図-13に はシマモラら（2007）の論文に示された実験結果の読取 值を併記しているが，計算と実験は良好に一致している.

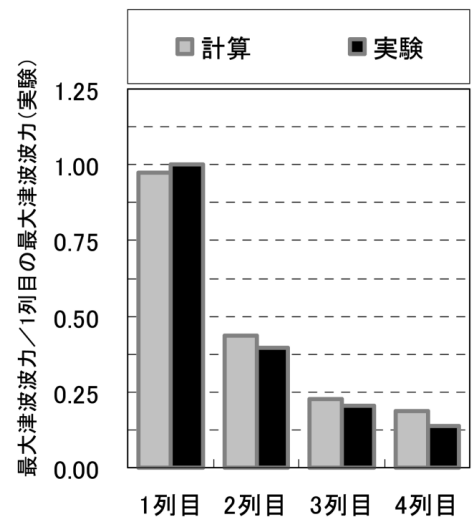

図-12 複数配置時の最大津波波力 （実験結果：シマモラら (2007)）

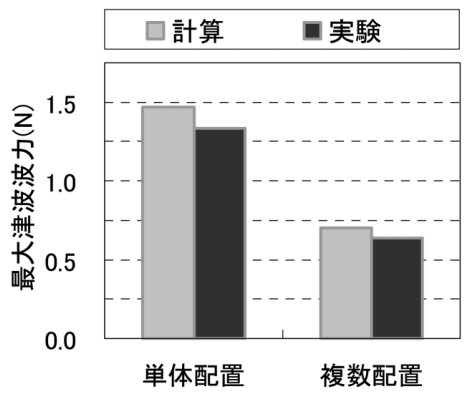

図-13 複数配置の影響

（護岸から 0.4m位置，実験結果：シマモラら（2007））
また，両者の護岸からの位置は同一であるものの，単体 配置の場合と複数配置の場合では津波波力が大きく異な り，後者の方が前者の $1 / 2$ 程度の波力となっている．計 算でもこのような傾向が定量的に再現されており，周辺 構造物の影響を考慮する場合における，3次元数值シミ ユレーションの有用性が確認された.

\section{5. まとめ}

本研究では，陸上構造物に作用する津波波力の評価に ついて沉用コードを用いた 3 次元数值シミュレーションの 適用性を検討した。その結果，以下の知見が得られた。

（1）朝倉ら（2000）の論文を参考として，3次元数值シ ミュレーションを行い，垂直壁に作用する遡上津波の 波圧を評価した。その結果，最大波圧が直線分布とな ること，海底勾配の違いによって波圧の大きさが異な ることが3次元数值シミュレーションでも定性的に再 現されることを確認した。

（2）シマモラら（2007）及び中村ら（2009）の論文を参 考として，3次元数值シミュレーションを行い, 矩形 構造物に作用する津波波力を評価した。その結果，複 数配置された矩形構造物の後列側における津波波力の 低下について, 計算結果と実験結果は良好に一致した。 この結果から，津波波力に対する周辺構造物の影響を 評価する際の, 3次元数值シミュレーションの有用性 を確認した。

朝倉ら（2000）やシマモラら（2007）の論文からも明 らかなように，津波波力の評価には，津波の陸上への遡 上過程と周辺構造物の影響を考慮することが重要とな る。その観点からは, 評価対象領域における地形や構造 物の配置・形状を直接再現する大規模な 3 次元数值シミ ユレーションが有用なッールの一つになり得るものと考 えられる，一方で，大規模な 3 次元数值シミュレーショ ンの実現には，計算効率と精度を両立する計算格子の構 成方法や，津波伝播解析からの境界条件生成等，開発す べき技術課題は多い。したがって，これらの取扱いが比 較的に容易である汎用コードの活用も，選択肢の一つに なり得るものと考えている.

\section{参 考 文 献}

中村友昭・水谷法美・藤間功司 (2009)：遡上津波の変形と陸 上構造物に作用する津波力に関する 3 次元数值シミュレ ーション, 第23回数值流体力学シンポジウム, G7-3.

朝倉良介・岩瀬浩二・池谷 毅 - 高尾 誠 - 金戸俊道・藤井 直樹・大森正憲（2000）：護岸を越流した津波による波力 に関する実験的研究, 海岸工学論文集, 第47巻, pp.911915.

チャルレスシマモラ・鴨原良典・藤間功司 (2007)：建物群に 作用する津波波力に関する水理実験，海岸工学論文集, 第 54 巻, pp.831-835. 